\title{
Pakkausmateriaalin, pakkauskoon ja säilytystavan vaikutus ruokaperunan laatuun
}

\author{
EERO VARIS \\ Hankkijan kasvinjalostuslaitos, Anttilan koetila, Hyrylä
}

Saapunut 22. 2. 1973

\section{The effect of material and size of package, and method of storing on the quality of the potato}

\author{
EERo VARIS \\ Plant Breeding Institute of Hankkija, Experimental Farm Anttila, Hyrylä, Finland
}

\begin{abstract}
Three different types of paper were used: Clupak (I), wet-strength (II), and kraft paper (III); and two LD-polyethylene films: black-pigmented, micro-perforated (IV), and transparent, perforated (V). The sizes of the packages were 2.5 and 5.0 kilos. Methods of storing: 1 week in a cold storeroom, followed by 7 or 13 days in a retail shop $(1+1$ and $1+2)$, and 6 days at home $(1+1+1$ or $1+2+1)$.

Weight loss of the potatoes was greater in paper bags than in plastic bags, and greater in small plastic bags than in the large ones. The potatoes moistured only slightly in paper bags, whereas moisturing was severe in plastic bags excepting the small micro-perforated bags. Sprouting of the potatoes was the strongest in plastic bags as well as in the wetstrength kraft paper bags. Greening of the potatoes was the slightest in the black-pigmented plastic bags, and by far the most severe in the transparent plastic bags. In this respect kraft paper bags proved less suitable than other paper bags. Potatoes rotted severely in the transparent perforated plastic bags as well as in the large black-pigmented micro-perforated plastic bags. The mealiness of the potatoes decreased during the treatment: slightly more in large bags than in the small ones. No evident differences were found between the materials. The flavour of the prepeeled, cooked potatoes had clearly deteriorated after one week in a retail shop $(1+1)$. Of the materials the transprarent polyethylene was graded as the poorest although compared to the other materials the difference was not significant.
\end{abstract}

Ruokaperunan pakkaaminen läpinäkyviin muovipusseihin yleistyi Suomessakin 1960-luvulla niin, että vuosikymmenen lopulla suurin osa ruokaperunasta pakattiin 1-5 kg:n muovipusseihin. Kun kuitenkin oli ilmeistä, että muovi ei ollut paras mahdollinen pakkausmateriaali huolimatta halpuudestaan ja kuluttajien suosiosta, järjestettiin muutamia asiaa selvittäviä tutkimuksia eri tahoilla. Yksi näistä oli Perunaseuran alaisuuteen lokakuussa 1968 perustetun Perunapakkausten kehittämistoimikunnan Hankkijan kasvinjalostuslaitoksella keväällä 1969 järjestämä tutkimus, jonka tulokset seuraavassa esitetään. 
Kokeen tarkoituksena oli verrata käytäntöä jäljittelevissä olosuhteissa harjaamattomien ja pesemättömien perunoiden laadun muuttumista muutamia pakkausmateriaaleja käytettäessä.

\section{Pakkausmateriaalit:}

$\begin{array}{lcl}\text { I } & \text { paperipussi } & \text { Clupak, mikrorei'itetty, märkäluja, } 80 \mathrm{~g} / \mathrm{m}^{2} \\ \text { II } & \text { märkäluja, } 80 \mathrm{~g} / \mathrm{m}^{2} \\ \text { III } & \text { voimapaperi, } 80 \mathrm{~g} / \mathrm{m}^{2} \\ \text { IV } & \text { muovipussi } & \text { LD-polyeteeni, mustapigmentoitu, mikrorei'itetty, paksuus } 0.05 \mathrm{~mm} \\ \text { V } & \text { LD-plyeteeni, kirkas, rei'itetty } \varnothing 6 \mathrm{~mm} \text {, paksuus } 0.05 \mathrm{~mm}\end{array}$

Pakkauskoot:
A $2.5 \mathrm{~kg}$
B 5.0 ,

Säilytystavat ja -ajat:

1. 1. Varastointi kuljet us pak ka u k is a (viileässä huoneessa $\mathrm{n} .+8^{\circ} \mathrm{C}$ lämpötilassa, isoissa märkälujissa säkeissä, pimeässä) 7 vrk.

2. $1+1$. Kohdan 1 jälkeen säilytys $v a ̈ h$ it tä is ka u pas sa (lämpimässä huoneessa n. $+15^{\circ} \mathrm{C}$ lämpötilassa, pöydille ladottuina, keinovalossa) 7 vrk.

3. $1+2$. Kohdan 1 jälkeen $\mathrm{v}$ ä h it t ä is k a u a s a $13 \mathrm{vrk}$.

4. $1+1+1$. Kohdan 2 jälkeen säilytys k o to n a (komerossa n. $+15^{\circ} \mathrm{C}$ lämpötilassa, pussit avattuina, pimeässä) 6 vrk.

5. $1+2+1$. Kohdan 3 jälkeen säilytys k o to n a 6 vrk.

Aineisto käsitti yhteensä 250 pakkausta.

Perunat analysoitiin kokeen alkaessa ja joka vaiheen jälkeen, jolloin kustakin erästä otettiin sokeasti 5 pakkausta. Seuraavat määritykset tehtiin:

1. Painon mutos. Pakkaukset punnittiin jokaisen käsittelyvaiheen lopussa.

2. Perunoiden kostuminen, paino- $\%$. Kostuneeksi luettiin peruna, jonka pinnasta yli $5 \%$ oli märkä pakkausta purettaessa.

3. Perunoiden itäminen, paino- \% . Itäneeksi luettiin peruna, jossa oli enemmän kuin yksi yli 1 mm:n mittainen itu.

4. Perunoiden pilaantuminen, paino- \%. Pilaantuneeksi laskettiin peruna, jossa oli selvästi havaittavissa sieni- tai bakteerivikaa.

5. Perunoiden vihertyminen, paino- $\%$. Vihertyneeksi katsottiin peruna, jonka pinnasta yli $5 \%$ oli vihertynyt.

6. Perunoiden jauhoisuus. Kts, seuraava.

7. Perunoiden maku. Keittokokeessa 5 edustavaa mukulaa keitettiin kuorittuina höyryssä. Jauhoisuus ja maku arvosteltiin laitoksen käyttämällä tavalla $0-100$ asteikolla, jossa $0=$ vetinen, voimakkaita sivumakuja, ruokaperunakelvoton, $100=$ hyvin jauhoinen, maultaan virheetön. Arvosteluaseikko on tarkemmin selostettu aikaisemmin (esim. VARIS 1972).

Koelajike oli Realta, josta valittiin pakkauksiin terveitä ja ehjiä mukuloita lajittelukoosta $40-55 \mathrm{~mm}$.

Tulokset käsiteltiin varsianssianalyysillä Keskusosuusliike Hankkijan ATKosastolla. Tulosten tilastollinen merkitsevyys on ilmaistu seuraavasti: 


$\begin{aligned} * * * & =99.9 \% \text { :n luotettavuus } \\ * * & =99 \\ * & =95 \\ \left(^{*}\right) & =90 \\ \text { ns } & =\text { ei luotettava }\end{aligned}$

\section{Tulokset ja tarkastelu}

Varianssianalyysin tulokset ja PME (5\%) on esitetty Taulukossa 1.

Taulukko 1. Varianssianalyysi pakkausmateriaalin, pakkauskoon ja säilytystavan vaikutuksesta perunan laatuun (suluissa PME $5 \%$ )

Table 1. Analysis of variance of the effect of material and size of package, and of the method of storing on the quality of the potato (LSD $5 \%$ within parentheses)

\begin{tabular}{|c|c|c|c|c|c|c|c|}
\hline & $\begin{array}{c}\text { Paino- } \\
\text { häviö } \\
\text { Weight } \\
\text { loss } \\
\%\end{array}$ & $\begin{array}{c}\text { Kostu- } \\
\text { neita } \\
\text { Moist } \\
\text { tubers } \\
\%\end{array}$ & $\begin{array}{l}\text { Itäneitä } \\
\text { Sprouted } \\
\text { tubers } \\
\%\end{array}$ & $\begin{array}{c}\text { Viherty- } \\
\text { neitä } \\
\text { Greened } \\
\text { tubers } \\
\%\end{array}$ & $\begin{array}{c}\text { Pilaan- } \\
\text { tuneita } \\
\text { Rotted } \\
\text { tubers } \\
\%\end{array}$ & $\begin{array}{c}\text { Jauhoi- } \\
\text { suus } \\
\text { Mealiness } \\
0-100\end{array}$ & $\begin{array}{c}\text { Maku } \\
\text { Flavour } \\
0-100\end{array}$ \\
\hline $\begin{array}{l}\text { I Materiaali ............ } \\
\text { Material }\end{array}$ & $* * *(0.3)$ & $* * *(6)$ & $* * *(4)$ & $* * *(7)$ & *** (6) & ns $(-)$ & $(-)$ \\
\hline A Koko - Size ...... & $* * \quad(0.2)$ & ns $(-)$ & ns $(-)$ & $* * *(5)$ & ns $(-)$ & $* \quad(2)$ & ns $\quad(-)$ \\
\hline $\begin{array}{c}1 \text { Säilytystapa ....... } \\
\text { Method of storing }\end{array}$ & $* * *(0.3)$ & $* * *(6)$ & $* * *(4)$ & $* * *(7)$ & $* * *(6)$ & $* * *(3)$ & $* * *(4)$ \\
\hline 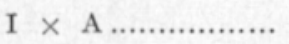 & $* * *(0.3)$ & $(*) \quad(7)$ & ns $(-)$ & ns $(-)$ & $* \quad(7)$ & $(-)$ & ns $(-)$ \\
\hline$I \times 1 \ldots \ldots \ldots \ldots \ldots$ & $* * *(0.5)$ & $* * *(11)$ & $* * *(5)$ & $* * *(13)$ & $* * *(12)$ & $(-)$ & $(-)$ \\
\hline $\mathrm{A} \times 1$ & $* * *(0.3)$ & $* \quad(7)$ & ns $(-)$ & ns $(-)$ & ns $(-)$ & $(-)$ & $(-)$ \\
\hline $\mathrm{I} \times \mathrm{A} \times 1 \ldots \ldots \ldots$ & ns $\quad(-)$ & ** (14) & ns $(-)$ & ns $(-)$ & $* * \quad(15)$ & - & - \\
\hline
\end{tabular}

P a i n o häviö. Eroja pakkausten painohäviössä aiheuttivat sekä pakkausmateriaali, pakkauskoko että säilytystapa (Taulukko 1, Piirros 1).

Muovipakkaukset eroittautuivat paperipusseista pienemmän painohäviönsä ansiosta (paperit $4.3,4.9$ ja 4.9 , muovit 2.6 ja $1.9 \%$ ). Pienten pakkausten painohäviö oli hiukan suurempi kuin isojen (3.8 ja $3.6 \%$ ). Pakkausten painohäviö lisääntyi melko suoraviivaisesti kokeen jatkuessa $(0.9,2.7,4.1,4.7$ ja $6.1 \%$, Piirros 1).

Ensimmäisen asteen merkitsevistä yhdysvaikutuksista kävi selville seuraavaa:

Isojen muovipakkausten painohäviö oli selvästi pienempi kuin pienten (materiaali $\times$ koko). Papereista voimapaperi (III) poikkesi muista siinä, että sen isoissa pakkauksissa painohäviö suureni. Merkitsevä yhdysvaikutus materiaali $\times$ säilytystapa osoitti lähinnä sen, että muovipakkausten painohäviö lisääntyi hitaammin kuin paperipakkausten. Ero oli selvempi isoissa pakkauksissa (koko $\times$ säilytystapa).

Viikon varastosäilytys (1) aiheutti pakkauskokoa huomioimatta muovipakkauksissa keskimäärin 0.5 ja paperipakkauksissa $1.2 \%$ :n painohäviön. 


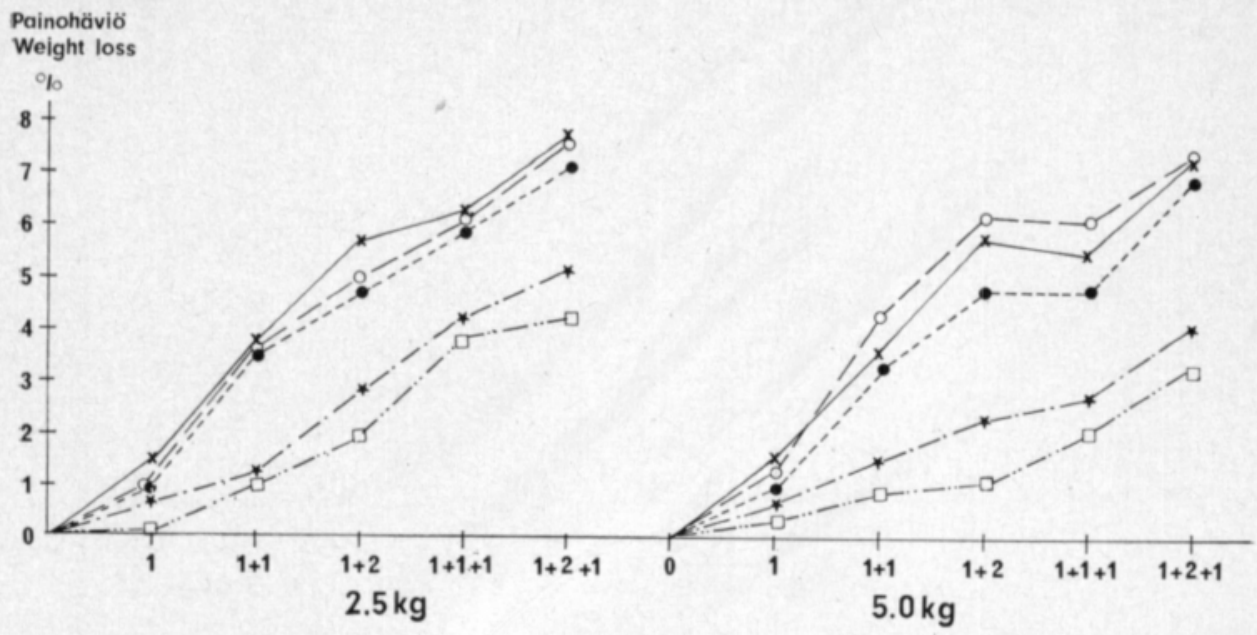

Piirros 1.Pakkausmateriaalin, pakkauskoon ja säilytystavan vaikutus perunoiden painohäviöön. Figure 1. The effect of material and size of package, and method of storing on the weight loss of the potatoes.

$$
\begin{array}{ll}
\bullet---\bullet & =\text { I Clupak } \\
\times-\times & =\text { II märkäluja }- \text { wet-strength } \\
0--\circ & =\text { III voimapaperi }- \text { kraft paper } \\
*-\cdots-* & =\text { IV mutsapigmentoitu, mikrorei'itetty muovi }- \text { black-pigmented, micro- } \\
& \quad \text { perforated plastic } \\
\square-\cdots-\square & =\text { V läpinäkyvä rei'itetty muovi }- \text { transparent perforated plastic. }
\end{array}
$$

Tämän jälkeinen lämmin säilytys vähittäiskaupan olosuhteissa nosti painohäviön kahdessa viikossa $(1+2)$ muovipakkauksissa 2.2. ja paperipakkauksissa $5.4 \%$ :iin. Kotisäilytys avonaisissa pusseissa nosti vielä kokonaispainohäviön $(1+2+1)$ vastaavasti 4.2 . ja $7.3 \%$ :iin (vrt. Ellala ym. 1970). Amerikkalaisissa tutkimuksissa on myös todettu polyeteenipakkauksissa painohäviön jäävän huomattavasti pienemmäksi kuin paperisissa (LUTZ ym. 1951, HARdenburg 1954). Chase (1964) totesi painohäviön olevan pienissä pakkauksissa prosentuaalisesti suuremman kuin isoissa. Painohäviö oli hänen tutkimuksissaan suurin alussa, kolmena-neljänä päivänä pakkaamisen jälkeen.

Perunoiden kost uminen. Varianssianalyysin (Taulukko 1) mukaan sekä pakkausmateriaali että säilytystapa vaikuttivat perunoiden kostumiseen (Piirros 2).

Perunoiden kostuminen eri pakkausmateriaaleissa oli keskimäärin: paperit 4, 6, ja 5, muovit 15 ja $39 \%$. Eri säilytystavoissa kostuneiden perunoiden osuudet olivat: $24,19,13,6$ ja $6 \%$.

Kaikissa paperipusseissa (I-III) koosta riippumatta perunat säilyivät käytännöllisesti katsoen kuivina. Samoin ne säilyivät kuivina mikrorei'itetyissä (IV) pienissä muovipusseissa. Sen sijaan mikrorei'itetyt isot muovipakkaukset kostuivat selvästi varastosäilytyksen (1) aikana, mutta kuivuivat myös selvästi kauppasäilytyksen $(1+1$ ja $1+2)$ aikana. Rei'itetyissä muovipusseissa (V) perunat kostuivat pahoin, mutta kotisäilytyksen aikana nekin kuivuivat lähes täysin (yhdysvaikutukset).

Samanlaisia tuloksia tavallisten ja myös rei'itettyjen muovipussien läpäi- 


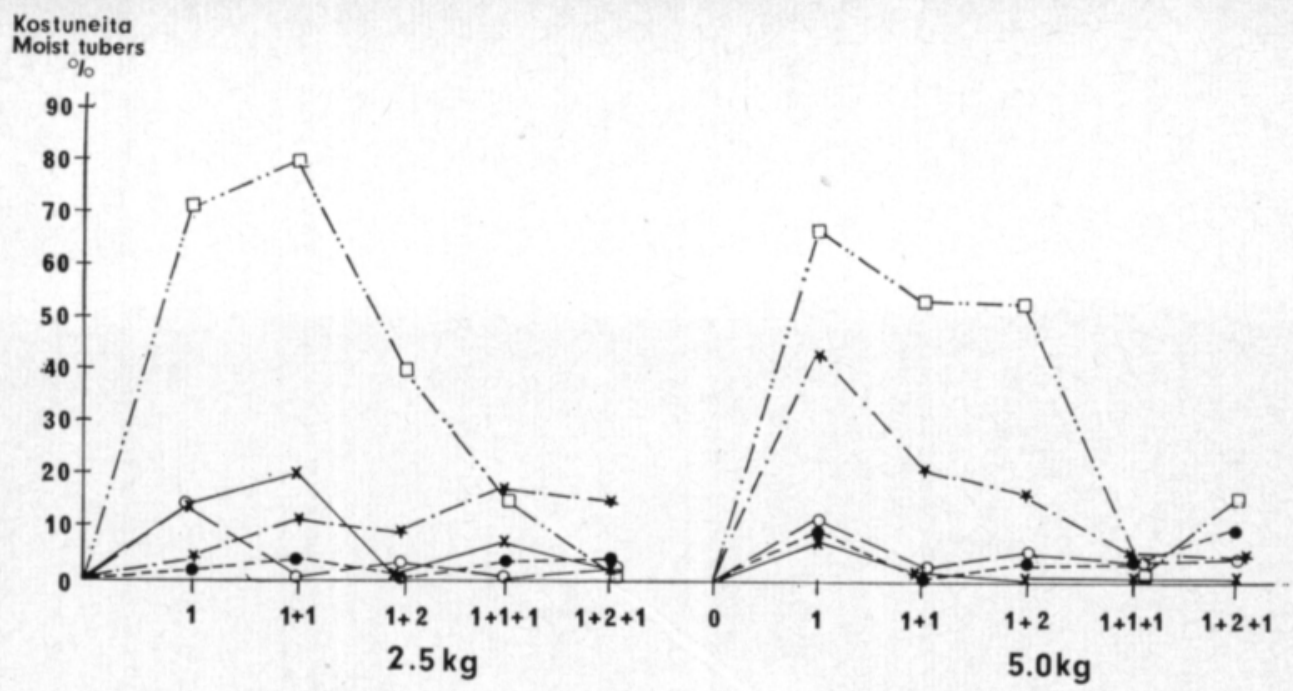

Piirros 2. Pakkausmateriaalin, pakkauskoon ja säilytystavan vaikutus perunoiden kostumiseen. Figure 2. The effect of material and size of package, and method of storing on the moisturing of the potatoes.
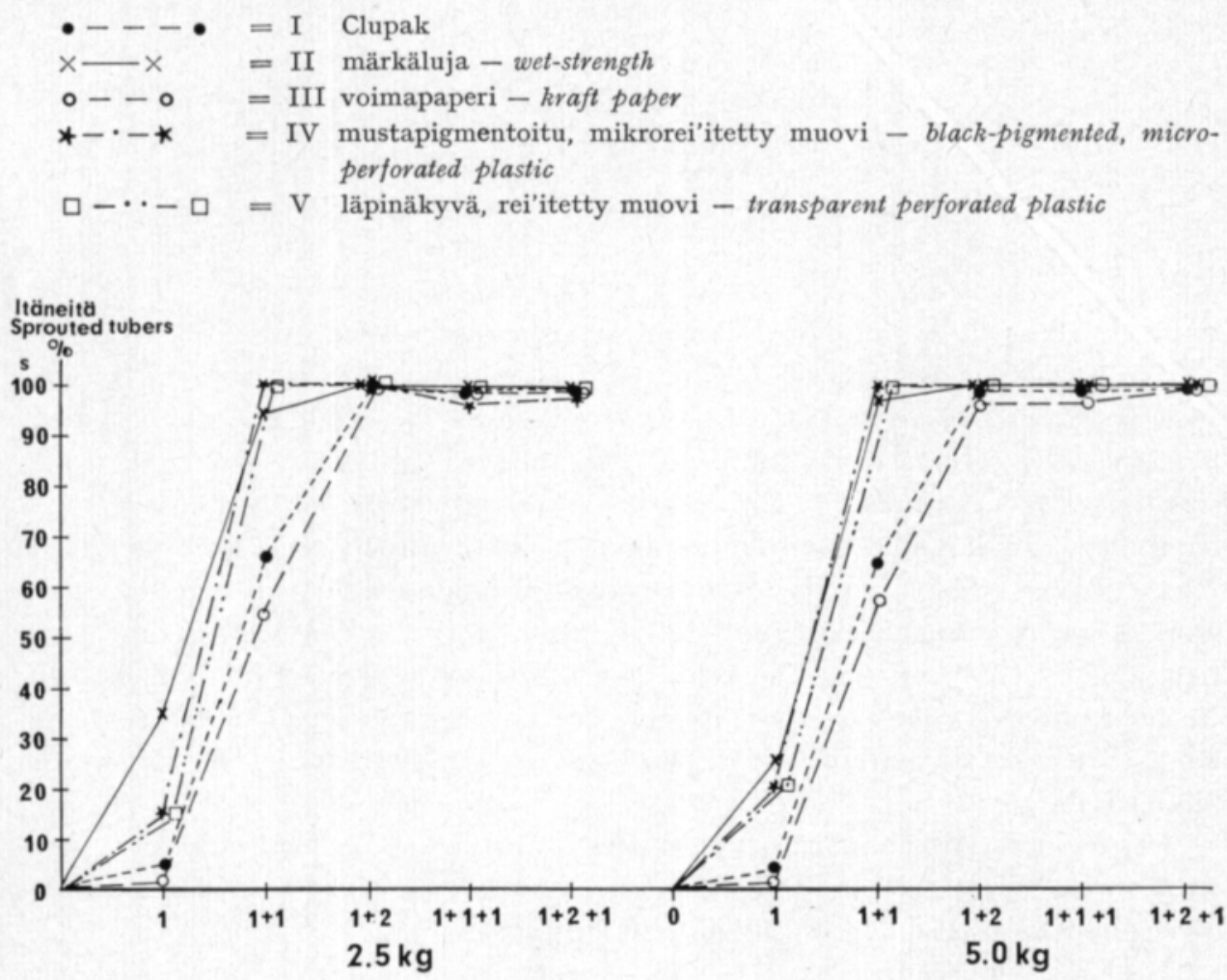

Piirros 3. Pakkausmateriaalin, pakkauskoon ja säilytystavan vaikutus perunoiden itämiseen. Figure 3. The effect of material and size of package, and methoa of storing on the sprouting of the potatoes.

$$
\begin{array}{lll}
\bullet---\bullet & =1 \quad \text { Clupak } \\
\times-\times & =\text { II märkäluja }- \text { wet-strength } \\
\circ--\circ & =\text { III voimapaperi }- \text { kraft paper } \\
*-\cdot-* & =\text { IV mustapigmentoitu, mikrorei'itetty muovi }- \text { black-pigmented, micro- } \\
& & \begin{array}{l}
\text { perforated plastic } \\
\square-\cdots-\square
\end{array}=\text { V läpinäkyvä, rei'itetty muovi }- \text { transparent perforated plastic }
\end{array}
$$


semättömyydestä ja kosteuden kondensoitumisesta on todettu muissakin vastaavissa tutkimuksissa (Lutz ym. 1951, Hardenburg 1954, Hechelmann ym. 1968, Ellala ym. 1970).

I t ä m i n e oli sangen nopeaa johtuen kokeen myöhäisestä suoritusajasta (Piirros 3).

Perunoiden itäminen eri materiaaleissa oli keskimäärin: paperit 73,85 ja 70 , muovit 83 ja $83 \%$. Tuloksesta näkyy, miten itäminen oli runsaampaa muovipusseissa kuin parhaissa paperipusseissa (vrt. Hechelmann ym. 1968). Papereista märkäluja (II) oli muita huonompi. Kun siinä perunat myös kostuivat osittain enemmän kuin muissa paperipusseissa, on syytä olettaa, että pussien kosteudenläpäisykyvyllä oli merkitystä perunoiden itämisnopeuteen. Parhaista paperilaaduista (I ja III) valmistetuissa pusseissa perunat itivät muita hitaammin, mutta lopuksi niissäkin itivät kaikki perunat (materiaali $\times$ säilytystapa).

Vihertyminen. Läpinäkyvissä muovipusseissa (V) perunoiden vihertyminen oli keskimäärin muita voimakkaampaa (paperit 22,16 ja 32 , muovit 5 ja $62 \%$ ). Sen sijaan märkälujissa (II) ja Clupak-(I) paperipusseissa vihertyminen oli selvästi vähäisempää ja mustapigmentoiduissa muovipusseissa (IV) vähäisintä (Piirros 4).

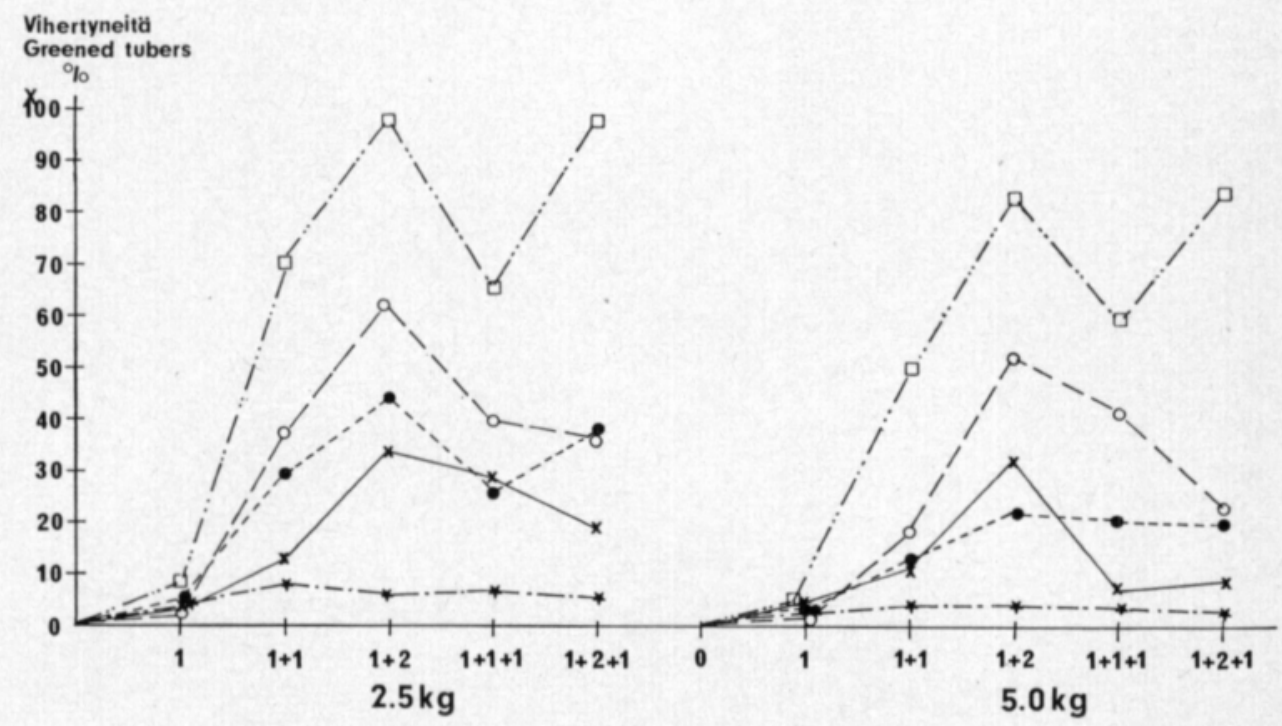

Piirros 4. Pakkausmateriaalin, pakkauskoon ja säilytystavan vaikutus perunoiden vihertymiseen.

Figure 4. The effect of material and size of package, and method of storing on the greening of the potatoes.

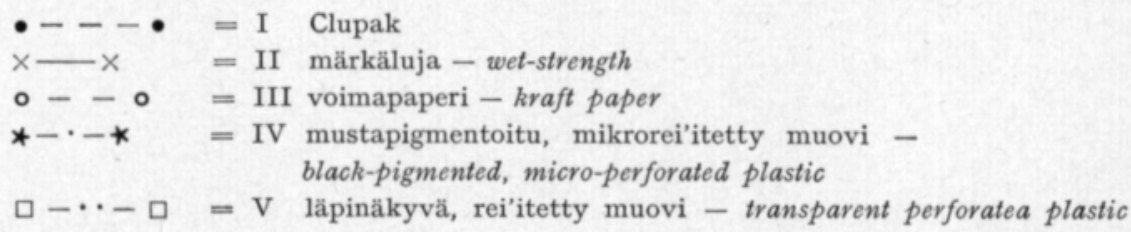


Pienissä pusseissa vihertyneitä mukuloita oli enemmän kuin isoissa (32 ja $23 \%$ ). Vihertyminen lisääntyi erityisesti vähittäiskaupan valoisassa säilytyksessä $(4,25,44,30,34 \%)$.

Yhdysvaikutuksen materiaali $\times$ säilytystapa mukaan vihertyminen edistyi materiaalista riippuen selvästi eri tavalla.

Amerikassa tutkittiin jo 1950-luvun alussa eri pakkausmateriaalien vaikutusta perunoiden vihertymiseen ja todettiin, että kahdeksan päivää 9 tunnin keinovalaistuksessa pidetyistä perunoista tavallisissa paperipusseissa vihertyi vain $1 \%$, läpinäkyvissä polyeteenipusseissa $71 \%$. Paperipusseissa polyeteeniaukko lisäsi huomattavasti vihertymistä (LUTz ym. 1951). Samoin Hardenburg (1954) totesi perunoiden vihertymisen olevan riippuvainen pakkausmateriaalin valonläpäisykyvystä. EllalA ym. (1970) totesivat suuren eron tavallisen läpinäkyvän ja mustapigmentoidun polyeteenipussin sekä myös voimapaperipussin valonläpäisykyvyn välillä. Samoin heidän kokeissaan vihertyminen mustapigmentoiduissa polyeteenipusseissa oli vähäisempää kuin voimapaperipusseissa ja läpinäkyvissä polyeteenipusseissa.

$\mathrm{Pil}$ a a $\mathrm{nt}$ minen. Varianssianalyysin mukaan perunoiden pilaantumisessa oli pakkausmateriaaleittain eroja (paperit 5,4 ja 7 , muovit 13 ja $63 \%$ ). Läpinäkyvä muovi (V) oli selvästi huonoin materiaali. Myös musta-

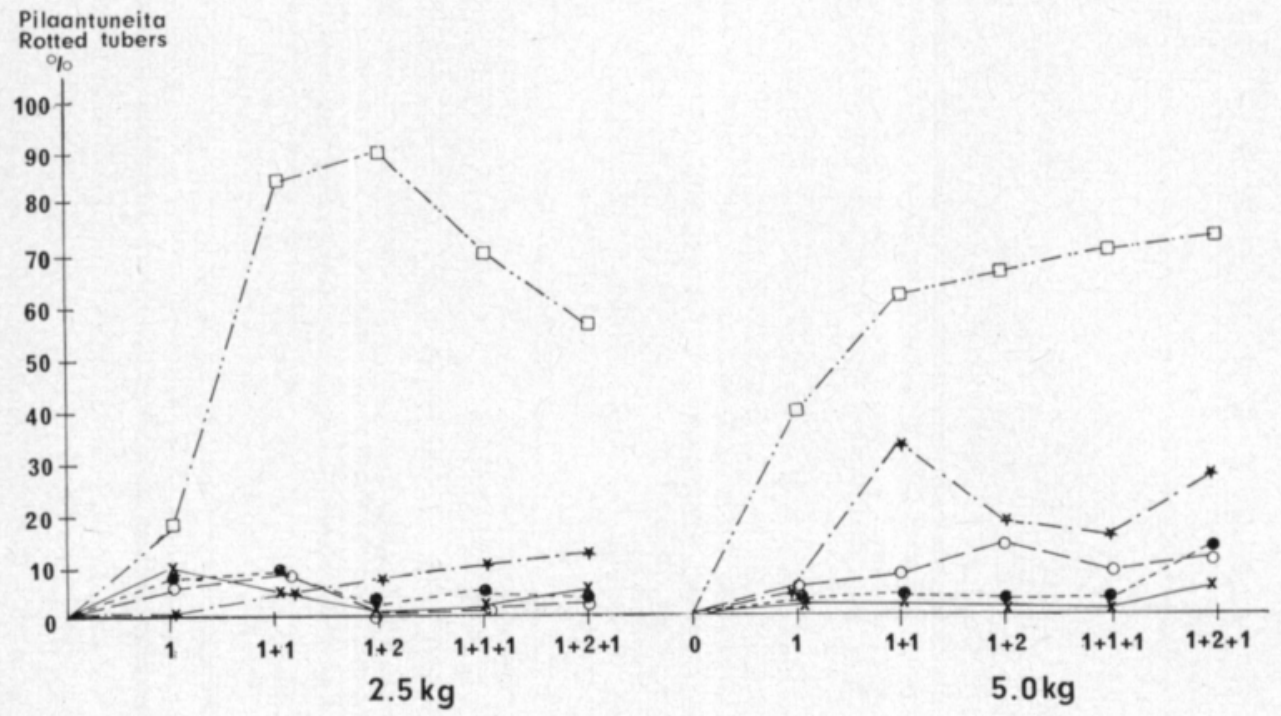

Piirros 5. Pakkausmateriaalin, pakkauskoon ja säilytystavan vaikutus perunoiden pilaantumiseen.

Figure 5. The effect of material and size of package, and method of storing on the occurrence of tuber rot.

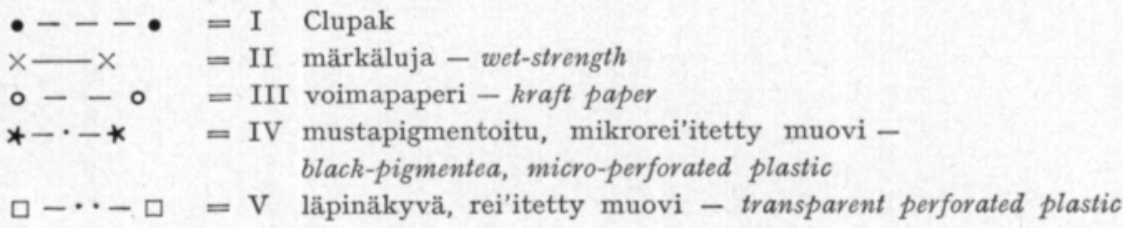


pigmentoitu muovi (IV) oli keskimäärin papereita huonompi. Säilytysajan jatkuminen lisäsi aluksi pilaantumista $(10,22,20,19$ ja $21 \%)$. Yhdysvaikutuksista (Taulukko 1, Piirros 5) käy selville, että paperipusseista tavallisesta voimapaperista (III) valmistetuissa isoissa pusseissa oli enemmän pilaantuneita kuin muissa paperipusseissa. Mustapigmentoitu, mikrorei'itetty muovi (IV) oli suhteellisen hyvä pieninä pakkauksina, mutta isoina papereita huonompi. Läpinäkyvä muovi (V) oli sekä pieninä että isoina pusseina ylivoimaisesti huonoin pakkausmateriaali (vrt. Lutz ym. 1951, Hechelmann ym. 1968).

J a u h o is u us. Perunat pysyivät jauhoisempina pienissä pakkauksissa (41 ja 39), vaikka ero olikin sangen pieni (Taulukko 1). Tämä voisi johtua pienten pakkausten suuremmasta painon (veden) häviöstä ja siis kuiva-ainepitoisuuden noususta.

Säilytysajan kuluessa jauhoisuus aluksi aleni, mutta nousi taas hiukan kotisäilytyksen aikana $(46,39,37,38$ ja 41$)$.

Pakkausmateriaali ei vaikuttanut merkitsevästi jauhoisuuteen (paperit 40, 41 ja 39, muovit 39 ja 41). Ellala ym. (1970) eivät myöskään todenneet eroa voimapaperin ja mikrorei'itetyn mustapigmentoidun polyeteenin välillä.

M a k u. Keittokokeessa kuorittuina keitetyissä perunoissa todettiin vain

Taulukko 2. Perunan maun muttuminen erilaisissa pakkauksissa.

Table 2. Changes in the flavour of the potatoes packed in different kinds of packages.

\begin{tabular}{|c|c|c|c|c|c|c|c|}
\hline \multirow{2}{*}{\multicolumn{2}{|c|}{$\begin{array}{l}\text { Materiaali } \\
\text { Material }\end{array}$}} & \multirow{3}{*}{1} & \multirow{2}{*}{\multicolumn{3}{|c|}{$\begin{array}{c}\text { Säilytystapa } \\
\text { Method of storing }\end{array}$}} & \multirow{3}{*}{$\frac{1+2+1}{48}$} & \multirow{3}{*}{$\begin{array}{c}\begin{array}{c}\text { Keskim. } \\
\text { Average }\end{array} \\
53\end{array}$} \\
\hline & & & & & & & \\
\hline I & Clupak ............................... & & 60 & 45 & 53 & & \\
\hline II & $\begin{array}{l}\text { mårkäluja } \\
\text { wet-strength }\end{array}$ & 58 & 60 & 50 & 48 & 48 & 53 \\
\hline III & $\begin{array}{l}\text { voimapaperi } \ldots \ldots \ldots \ldots \ldots \ldots \ldots \ldots \ldots \\
\text { kraft paper }\end{array}$ & 60 & 60 & 43 & 48 & 53 & 53 \\
\hline IV & $\begin{array}{l}\text { mustapigmentoitu } . . . \ldots \ldots \ldots \ldots \ldots \\
\text { black-pigmented }\end{array}$ & 55 & 60 & 48 & 50 & 48 & 52 \\
\hline V & $\begin{array}{l}\text { läpinäkyvä } \ldots \ldots \ldots \ldots \ldots \ldots \ldots \ldots \ldots \ldots \ldots \ldots \ldots \ldots \\
\text { transparent }\end{array}$ & 63 & 55 & 40 & 40 & 45 & 49 \\
\hline Kes! & skim. - Average ......... & 59 & 59 & 45 & 48 & 48 & - \\
\hline
\end{tabular}

vähäisiä makueroja (Taulukko 1). Pakkausmateriaalien välillä ei ollut merkitsevää eroa (Taulukko 2), vaikkakin läpinäkyvä polyeteeni (V) sai muita heikompia arvosanoja. Pakkauskokojen välinen ero ei myöskään ollut merkitsevä (53 ja 51). Säilytysajan kuluessa maku huononi selvästi yhden viikon kauppasäilytyksen $(1+1)$ jälkeen (Taulukko 2). Yhdysvaikutukset eivät olleet merkitseviä, joskin materiaali $\times$ säilytystapa näytti perunoiden laadun huononevan nopeimmin läpinäkyvissä muovipusseissa (V, Taulukko 2). 
Suoritettu tutkimus oli tarkoitettu perustan saamiseksi kotimaisiksi suosituksiksi perunan pakkausmateriaaleista. Pakkausmateriaaleiksi oli valittu käytössä olevia paperi- ja polyeteenilaatuja. Pakkausteollisuuden taholta ei ollut tarjolla uusia riittävän halpoja ratkaisuja.

Tästä samoin kuin referoiduista tutkimuksista käy selville, että läpinäkyvä muovikalvo on sangen huono perunoiden pakkausmateriaali rei'itettynäkin. Sen vuoksi sitä suositellaan muuallakin vain päivittäiseen käyttöön (HARDENBURG 1954). Perunat kostuvat, itävät ja pilaantuvat siinä nopeasti ja varsinkin vihertyvät jo muutamassa päivässä.

Perunoiden vihertymisen on todettu olevan niin nopeaa, että se sinänsä rajoittaa valoa läpäisevien pakkausmateriaalien käyttöä. Vihertymisen aiheuttamia laatuvirheitä on useissa tutkimuksissa todettu (LUTz ym. 1951, HARDENBURG 1954) varsinkin kuorineen keitetyissä perunoissa. Selostettavassa tutkimuksessa kuorituissa perunoissa todetut laatuvirheet eivät olleet merkitseviä. Suomessa voimassa olevissa ruokaperunan virallisissa laatuvaatimuksissa tulkitaankin vihertyminen laatuviaksi lievennetyssä muodossa: "vihertyneiksi katsotaan sellaiset mukulat, joista vihertyminen ei tavanomaisessa kuorinnassa häviä».

Tulosten perusteella Perunapakkausten kehittämistoimikunta omaksui seuraavat periaatteet (ANON. 1969):

Pakkauskooksi suositellaan 2.5, 5.0, 10 ja $25 \mathrm{~kg}: \mathrm{n} \mathrm{kuluttajapak-}$ k a u kia lähinnä saksalaisten standardien pohjalta (Hechelmann ym. 1968). K u l jetus- ja varastopak ka usiksi suositellaan $25 \mathrm{~kg}: \mathrm{n}$ pakkauksia $(10 \times 2.5$ tai $5 \times 5 \mathrm{~kg})$. Lisäksi suositellaan $40 \mathrm{~kg}$ :n s u u r k u l u t$\mathrm{t}$ a j a p k k a k si a.

Pakkausmateriaaliksi suositellaan yleiskäyttöön $\mathrm{m}$ ä $\mathrm{rk}$ äl u j a a $80 \mathrm{~g}: \mathrm{n}$ voima pa peria (II), joka sekä perunoiden säilymisen kannalta että hinnaltaan osoittautui edulliseksi. Sitä suositellaan 1-kertaisena 2.5 ja 5 kg:n pakkauksiin, 2-kertaisena $10 \mathrm{~kg}$ :n kuluttajapakkauksiin ja $25 \mathrm{~kg}: \mathrm{n}$ kuljetuspakkauksiin, 3-kertaisena $25 \mathrm{~kg}: n$ kuluttajapakkauksiin ja 4-kertaisena $40 \mathrm{~kg}: \mathrm{n}$ suurkuluttajapakkauksiin.

Lisäksi suositellaan $2.5 \mathrm{~kg}: \mathrm{n}$ pakkauksiin mikrorei'itettyä, mustapigmentoitua polyeteeniä.

\section{Yhteenveto}

Kevättalvella 1969 järjestettiin Hankkijan kasvinjalostuslaitoksella Perunaseuran alaisen Perunapakkausten kehittämistoimikunnan toimesta tutkimus, jossa selvitettiin perunan säilymistä ja laadun muutoksia kolmesta paperilaadusta (Clupak, märkäluja ja voimapaperi) ja kahdesta polyeteenilaadusta (mustapigmentoitu mikrorei'itetty ja läpinäkyvä rei'itetty) tehdyissä 2.5 ja 5 kg:n pakkauksissa varasto-, kauppa- ja kotisäilytyksen aikana.

Tämän tutkimuksen tulokset voidaan tiivistää seuraaviin johtopäätöksiin:

Perunoiden painohäviö vähittäiskaupan pakkauksissa vaihteli pakkausmateriaalin mukaan. Se oli suurin paperipusseissa, joissa se yhden viikon 
varastosäilytyksen aikana nousi keskimäärin $1.2 \%$ :iin, sitä seuranneena kahden viikon kauppasäilytyksen aikana $5.4 \%$ :iin sekä sen jälkeen kotisäilytyksessä jopa $7.3 \%$ :iin. Polyeteenipusseissa painohäviö oli huomattavasti pienempi: $0.5-2.2-4.2 \%$. $5 \mathrm{~kg}$ :n polyeteenipusseissa painohäviö oli pienempi kuin $2.5 \mathrm{~kg}: \mathrm{n}$ pusseissa.

Perunoiden kostuminen oli harvareikäisissä polyeteenipusseissa niin nopeaa, että jo yhden viikon varastosäilytyksen jälkeen $69 \%$ perunoista oli märkiä. Myös mikrorei'itetyissä isoissa polyeteenipusseissa kostui yli $40 \%$ perunoista yhden viikon aikana. Paperipusseissa perunat säilyivät moitteettoman kuivina koko kokeen ajan.

Perunoiden itäminen oli nopeinta polyeteenipusseissa sekä märkälujasta voimapaperista tehdyissä pusseissa.

Käytetyt pakkausmateriaalit vaikuttivat hyvin eri tavalla perunoiden vihertymiseen. Vihertyminen oli vähäisintä mustapigmentoiduissa polyețeenipusseissa, joissa vihertyneitä mukuloita yhden viikon varastosäilytyksen ja kahden viikon vähittäiskauppasäilytyksen jälkeen oli vain $0.5 \%$. Paperilaaduista tavallinen voimapaperi oli muita huonompi $(57 \%$, muut paperilaadut keskimäärin $33 \%$ ). Selvästi epäedullisin oli läpinäkyvä polyeteeni $(91 \%)$.

Perunoiden pilaantuminen noudatti selvästi kostumistuloksia. Se oli vähäistä paperipusseissa, selvästi runsaampaa mikrorei'itetyissä isoissa polyeteenipusseissa sekä ylivoimaisesti runsainta läpinäkyvissä harvareikäisissä polyeteenipusseissa.

Perunoiden jauhoisuudessa ei ollut selviä eroja pakkausmateriaalien välillä. Pienissä pusseissa jauhoisuus oli hiukan parempi kuin isoissa. Jauhoisuus aleni kokeen aikana.

Kuorittuina keitettyjen perunoiden maku huononi kokeen kuluessa. Merkitseviä eroja ei todettu materiaalien eikä pakkauskokojen vaikutusten välillä, joskin läpinäkyvään polyeteeniin pakatut perunat saivat muita huonompia arvosanoja.

\section{KIRJALLISUUS}

ANON. 1969. Ruokaperunan pakkausnormit. Perunaseura. Helsinki.

CHASE, R. W. 1964. Changes in weight of potatoes in consumer packs during marketing. Amer. Potato J. 41: $367-373$.

Ellala, A., Vanhanen, L. \& Kurkela, R. 1970. Pestyn perunan säilyvyys neularei'itetyssä muovissa. Maatal.tiet. Aikak. 42: 180-191.

HARDENBURG, R. E. 1954. Comparison on polyethylene with various other 10-pound consumer bags for Sebago, Katahdin, and Green Mountain potatoes. Amer. Potato J. 31: 29-39.

Hechelmann, H. G., Schepke, F., Schumacher, G., Windaus, G., Petermann, E., StaudenMAIER, P. \& FolK, S. 1968. Kartoffeln in Säcken. Verpackungs-Magazin 1968: 1-16.

Lutz, J. M., Findlen, H. \& Ramsey, G. B. 1951. Quality of Red River Valley potatoes in various types of consumer packages. Amer. Potato J. 28: 589-602.

VARIS, E. 1972. The effects of increasing NPK rates on the yield and quality of the Pito potato. II. External and internal quality. Acta Agr. Fenn. 128,2: 1-23. 